\title{
Model Residential School Education to Scheduled Caste Pupils in Kerala
}

\section{OPEN ACCESS}

Manuscript ID:

ECO-2021-09023599

Volume: 9

Issue: 2

Month: March

Year: 2021

P-ISSN: 2319-961X

E-ISSN: 2582-0192

Received: 14.12 .2020

Accepted: 10.02.2021

Published: 01.03.2021

Citation:

Rejimon, PM, and R.

Smitha. "Model Residential

School Education to

Scheduled Caste Pupils

in Kerala." Shanlax

International Journal of

Economics, vol. 9, no. 2,

2021, pp. 31-36.

DOI:

https://doi.org/10.34293/

economics.v9i2.3599

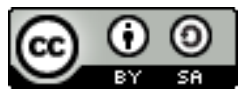

This work is licensed under a Creative Commons Attribution-ShareAlike 4.0 International License

\section{P.M. Rejimon}

Associate Professor, Post Graduate \& Research Department of Economics

Mar Dionysius College, Pazhanji, Thrissur, Kerala, India

(D) https://orcid.org/0000-0001-8998-9959

\section{R. Smitha}

Assistant Professor, Post Graduate \& Research Department of Economics

Sri C Achutha Menon Government College, Thrissur, Kerala, India

\begin{abstract}
There are about forty lakh scheduled caste people in Kerala. Most of them are poor and daily wage workers. The socio-economic backwardness of scheduled caste people is a historically determined outcome of a caste system in India. Education is the only way for them to get out of this historical whirlwind of economic deprivation, denial of rights and social exclusion. The Government of India passed The Right to Education Act in 2010 and it ensures "free and compulsory education" for all children aged 6 to 14. The government of Kerala has introduced many innovative programs to provide education for scheduled caste pupils in the state. "Model Residential School" owned and managed by the Scheduled Caste Development Department of The Government of Kerala, is one of such successful initiatives. Model Residential Schools take special care to cater to the educational needs of the underprivileged children and help them to attain quality education. In this article, the investigators explore the role played by the model residential schools in the educational development of scheduled caste pupils in Kerala and particularly in solving the burning issue of a high rate of dropouts among scheduled caste pupils.
\end{abstract}

Keywords: Model residential school, Scheduled caste, Development department, Education, Dropouts, Bright scheduled caste students

\section{Introduction}

In 1950 the Government of India promulgated a Scheduled caste list as per article 341 of the constitution of India. Thus a caste specified as scheduled caste and included in the list is only by the concurrence of the president of India. Hence the term scheduled caste is a constitutional term and not a sociological or political term like 'Dalit.' A caste that faces caste discrimination, isolation from the main-stream, having low economic and social status, backward in education, low representation in trade and commerce, far behind in industrial activities and least representation in government services may be included in the SC list. Many affirmative action's including reservation in representation, education and employment, are provided for the uplift of scheduled caste populations in India.

According to the 2011 census, total population's 17 percent are of scheduled caste population in India and 9 percent of Kerala's total population comprises the scheduled caste population. Among this, 76 percent and 60 percent of scheduled caste in India and Kerala reside in rural areas. These people reside in rural areas because they are agricultural laborers and bonded laborers. 
These occupations are imposed on them by the so-called upper caste because scheduled caste people are untouchable and illiterate. So they face atrocities, injustices, exploitation and oppression. Social reformers of India and Kerala fought against the then situation and those want to uplift the social and economic status of scheduled caste.

Scheduled caste occupies the lowest position in the Hindu social structure in India and Kerala. Scheduled caste people had been living and dying for their feudal masters in India and Kerala. The most remarkable and striking feature of Kerala history was the awakening of Scheduled caste people. They understood the root cause of their downtrodden and lowly status, not their birth, but caste system, economic deprivation, denial of rights and lack of education. Reformers among Scheduled castes fought for education, human rights and due share of economic resources. The basic hindrance in the education of scheduled caste people is lack of money, so the government of Kerala adopted various measures to uplift the educational status of scheduled caste by providing educational concessions, reservation, scholarship, residential schools, noon meal programs, hostel facilities, etc. The model residential school system is one of them.

The scheduled caste Development Department and Government of Kerala adopt the residential model schooling for the scheduled caste pupil because it is entirely different from regular- general educational institutions. The residential school provides an opportunity for a pupil to study and live together; this creates a circumstance to overcome their anxious and inclusive nature about management, relationship and learning. Ancient India experienced Residential Schooling, but it is purely for the elite group of Indian Society. So Residential schooling is not a new form of the educational system. To provide quality education to deprived and excluded caste in education, States tried to use this means (Report of CBPS, 2015).

Low educational status of deprived caste, especially Scheduled caste and Scheduled tribes face rebuff from the so-called elite group it leads to introvert nature among these people, to uplift the social-economic status as well as inner confidence between them, Education is an inevitable tool. So in the year 1997-98, the Ministry of Tribal Affairs has implemented the Ekalavya Model Residential School in the 22 states of the country; Kerala is one among the selected State (Baiju \& Ragi, 2014). On the footing of this educational scheme of the Central Government, Govt. of Kerala and Scheduled caste Development Department of Kerala also implements the Model residential School for bright scheduled caste students, whose parents are not able to provide proper education for their children because of the poor financial situation(Handbook of the Scheduled caste Development Department).

\section{Model Residential School}

Scheduled caste Development Department of Kerala implemented development programs for the benefit of the scheduled caste people of Kerala and it may be classified into three main heads; Educational Development programs, Economic Development programs and Social Development programs (SC Development Department of Kerala). Under these programs, the department gave priority to educational development programs. Dropouts from educational institutions are seen more among scheduled caste students than other category students. SC students' poor socio-economic environments contribute much to their exceptionally high dropout rate. To reduce the dropout rate at the school level government of Kerala and Scheduled caste Development Department established Model Residential School in various districts of Kerala. The MRS (Model Residential School) provides quality education to talented and economically - socially depressed scheduled caste students (SC Development Dept, Kerala).

The Administration and Supervision of Model Residential School are vested in the Administrative Committee. The following officials are in the Administrative Committee.

- District Collector (Concern District of MRS) Chairman

- District Scheduled Caste Development Officer Secretary

- Deputy Director, General Education - Member

- District Medical Officer - Member

- Headmaster / Headmistress (Respective MRS) - Member (Handbook of Scheduled caste Development Department) 
This committee has the full responsibility of the Selection of the Pupils and Teachers of Model Residential School. Teachers of the General Education Department, interested and willing to upgrade the scheduled caste students, are selected. All Model Residential School follows the Kerala state syllabus. So the Academic activates of the model residential school controlled by the General Education Department and the Administration of the model residential school controlled by the Scheduled caste development department (Handbook of Scheduled caste Development Department)
The Scheduled Caste Development Department runs nine Model Residential Schools in the Selected Districts of Kerala. The institution provides better and outstanding education to scheduled caste children from 5 th standard to 12 th standard. Students are selected in the Model Residential School based on the entrance exam conducted by the Scheduled Caste Development Department at State Level. The prime importance of the Model Residential School is to provide quality education to the socially and economically backward people of the scheduled caste. The mission of the Model residential school is to reduce the drop-out rate among the scheduled caste students in general education.

Table 1: Details of Model Residential Schools in Kerala

\begin{tabular}{|l|l|c|l|c|c|}
\hline S.No & \multicolumn{1}{|c|}{ Districts } & MRS (No.s) & \multicolumn{1}{|c|}{ MRS (Place) } & Establishment Year of MRS & Types of MRS \\
\hline 1 & Kasaragod & 1 & Vellachal & 2002 & Boys \\
\hline 2 & Kozhikode & 1 & Ulliyeri & 2003 & Boys \\
\hline 3 & Palakkad & 2 & $\begin{array}{l}\text { Thrithala } \\
\text { Kuzhalmannam }\end{array}$ & $\begin{array}{c}\text { Girls } \\
\text { Boys }\end{array}$ \\
\hline 4 & Thrissur & 2 & Wadakkanchery & 2010 & $\begin{array}{c}\text { Boys } \\
\text { Boys }\end{array}$ \\
\hline 5 & Ernakulam & 1 & Aluva & 2011 & Boys \\
\hline 6 & Idukki & 1 & Peerumedu & 2001 & Mixed \\
\hline 7 & Alappuzha & 1 & Punnapravadakkal & 2000 & Girls \\
\hline 8 & Thiruvananthapuram & 1 & Vellayani & 2002 & Mixed \\
\hline & (sports school) & Total & $\mathbf{1 0}$ & \multicolumn{2}{|}{} \\
\hline
\end{tabular}

Source: Scheduled Caste Development Department

The Scheduled Caste Development Department selected the districts for starting Model residential schools based on scheduled caste population, their economic and social backwardness, dropout ratio of students and attitude of the scheduled caste people. Most of the students in the Model residential schools are from socially, economically and culturally disadvantaged households. Parents of these students are first-generation literates and they are not literate enough to mentor their children. A residential school system can fill this generational gap of educational needs of the present generation of scheduled caste pupils.
Table 2 Educational Status of Scheduled Castes Students in Kerala (in lakhs)

\begin{tabular}{|c|c|c|}
\hline Class / Courses & Total Students & $\%$ \\
\hline Lower Primary & 1.44 & 30.31 \\
\hline Upper Primary & 1.19 & 24.95 \\
\hline High School & 1.12 & 23.53 \\
\hline Higher Secondary & 0.50 & 10.50 \\
\hline Degree and Post-Graduation & 0.30 & 6.30 \\
\hline $\begin{array}{l}\text { Diploma (ITI, ITC, } \\
\text { Certificate courses) }\end{array}$ & 0.19 & 3.99 \\
\hline $\begin{array}{l}\text { Professional Courses } \\
\text { (Engineering and Medicine) }\end{array}$ & 0.02 & 0.42 \\
\hline Total & 4.76 & $100 \%$ \\
\hline
\end{tabular}

Source: Scheduled caste - State Report, 2011 
The scheduled shows that as the educational level increases the enrollment of scheduled caste students declines. This is because of the poverty, lack of accessibility of higher-level educational institutions, failure and caste inferiority etc.

Figure 1: Gender wise Educational Status of Scheduled Castes Students in Kerala (in lakhs)

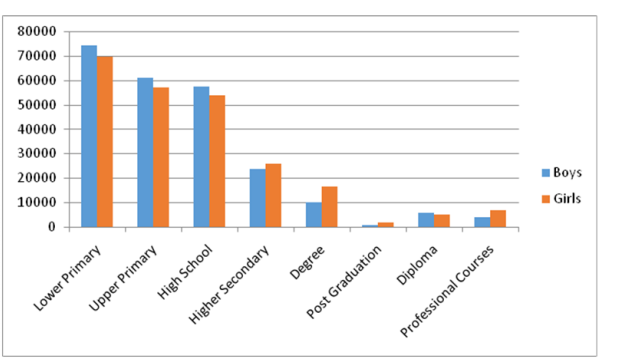

Source: Scheduled caste - State Report, 2011

The Figure shows that up to high school level enrollment of boys (52\%) is slightly higher than girls $(48 \%)$. As higher the educational level the enrollment of girls is much higher than boys $(52 \%, 62 \%$ and $72 \%$ of girls' enrollment in higher secondary, Degree and Post -Graduation respectively). Again boys' enrollment is a slight increase in the Diploma courses $(53 \%)$ than girls. The striking feature is that the enrollment of girls $(63 \%)$ is higher than boys in Professional courses. But we can see that the enrollment of boys and girls, shows a declining trend as educational level increase, it may be because of an economic hindrance, and higher education and professional education requires more finance than general education even though the scheduled caste development department provides lump-sum grant and scholarships to the students. Still, it was not sufficient to complete the courses. Apart from that, up to higher secondary level scheduled caste students to have the accessibility of educational institutions to their locality or nearby locality, but there is a lack of accessibility of higher educational institutions.

Table 3: Dropouts of Scheduled Caste Students in Educational Level

\begin{tabular}{|l|c|c|}
\hline \multicolumn{1}{|c|}{ Class / Courses } & $\begin{array}{c}\text { Total No. of } \\
\text { Students }\end{array}$ & \% \\
\hline Lower Primary & 1037 & 1.88 \\
\hline Upper Primary & 3959 & 7.16 \\
\hline
\end{tabular}

\begin{tabular}{|l|c|c|}
\hline High School & 33147 & 59.91 \\
\hline Higher Secondary & 11861 & 21.44 \\
\hline Degree and Post-Graduation & 4051 & 7.32 \\
\hline $\begin{array}{l}\text { Diploma (ITI, ITC, } \\
\text { Certificate courses) }\end{array}$ & 1127 & 2.04 \\
\hline $\begin{array}{l}\text { Professional Courses } \\
\text { (Engineering and Medicine) }\end{array}$ & 136 & 0.25 \\
\hline \multicolumn{1}{|c|}{ Total } & $\mathbf{5 5 3 1 8}$ & $\mathbf{1 0 0 \%}$ \\
\hline
\end{tabular}

Source: Scheduled caste - State Report, 2011

The schedule shows that at every educational level, there exist dropouts. Among dropouts, the majority (59.91 percent) dropouts in high school level. These huge numbers of dropouts occur because of poverty in the family, economic backwardness, lack of accessibility of educational institutions, difficulty in traveling, failure in the class/courses, caste inferiority and, marriage (in the case of girls).

Figure 2: Gender wise Dropouts of Scheduled Caste Students in Educational Level

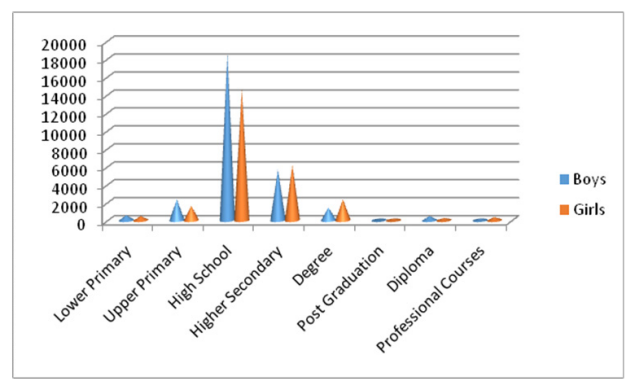

Source: Scheduled caste - State Report, 2011

The figure shows that the dropouts are higher in boys $(56 \%)$ than girls in elementary educational level (Lower Primary, Upper Primary and High school), after that as educational level increases the dropouts of girls are higher than boys $(52 \%, 62 \%$ and $70 \%$ of dropouts of girls in higher secondary, Degree and Post- graduation respectively). The Right to Education Act ensured the free and compulsory quality elementary education to all children aged 6 to 14 in India without considering Sex, Gender, Caste and Creed. We can see that the dropouts in elementary education are more in boys than girls. There are many reasons for the dropouts. The main reasons are a failure in the lower classes in school education (36\%) and sudden and immature decision, demonstration effect, lack of interest in studying, etc. $(40 \%)$. The main concern of Model residential 
school is to reduce the drop-out of scheduled caste students at the elementary education level. Therefore, the Model residential school provides the best learning experience to scheduled caste students who are economical - socially backward in society. Model residential schools provide better schooling for both girls and boys even though, concentrates on scheduled caste boy's education.

The model residential school is a shelter home of unrecognized and unwanted talented and brilliant scheduled caste students of Kerala; here, beliefs, attitudes, behavior, tolerance and acceptance of life and education are restructured and remolded. To provide a better and best teaching-learning process, the ratio of teacher-student is $1: 35$. The motto of model residential schools is to select students to acquire a better educational situation than Government and Aided schools where the majority of scheduled caste students enrolled.

The Model Residential School is fully controlled by the Scheduled caste Development Department; it is like an ashram type educational institution where students and teachers live together. The Department established this institution mainly for two reasons, one is to provide better education to scheduled caste students from 5th standard onwards and another one is to reduce the dropout ratio of the scheduled caste students in the General educational level. Those students who acquire high marks in the state level examination conducted by the Scheduled caste Development Department are selected to the Model Residential School. Apart from the entrance test, another main criterion for the selection is the annual income of the parents. It must be below $1,00,000 /-$

\section{Conclusion}

Basic features of the scheduled caste children are socio-cultural alienation, lack of confidence, introverted nature, fearful and timid in social interactions. Model residential schools provide scheduled caste children safe and protected social space of justice, equality and brotherhood and an enlightened atmosphere conducive for acquiring quality education without any fear or feeling of inferiority. The teachers provide knowledge and support according to each child's ability, efficiency, capability, intellectual aptitude and attitude. These facts reduce the scheduled caste students drop out in the General education. In the year 2013-14, the total dropouts in Kerala was 10,343 among this, 1187 students were scheduled caste $(12 \%)$ and the year 2017-18, total dropouts was 5960 students among this scheduled caste students drop out was $502(8 \%)$, it was far better from the year 2010-11, total dropouts were 22,914 among this 2619 students was Scheduled caste (Directorate of Public Institution, Economic Review, 2012, 2015 and 2018). We can say that the Model Residential School is a wing of talented scheduled caste children, but this wing was attached to their body. The purpose of the wing was to fly in the sky; only $10 \%$ of talented and competent students have permanent employment (Public Administration Department, Economic review 2018). The Model Residential School can give wings to the dreams of scheduled caste children if the institution widens its coverage, accessibility and infrastructures. When we objectively assess the positive achievements of the model residential school system in Kerala and that is truly reflected in the life of scheduled caste pupils, we can understand the essence of Nelson Mandela's great message "'"Education is the most powerful weapon which you can use to change the world ".

\section{References}

Dash, Neena. "Educational Status of Tribal Children in Ekalavya Model Residential Schools in English Language: Strengths, Concerns and Challenges of Implementation." Online International Interdisciplinary Research Journal, vol. 8, 2018, pp. 244-250.

Dhende, Lata Digambar. "A Study of Scheduled Caste and Higher Education Scenario in India." International Journal of Engineering Technology Science and Research, vol. 4, no. 11, 2018, pp. 345-351.

District Census Handbook, Village and Town Directory, Kerala, 2011.

George, K.K. "Higher Education in Kerala: How Inclusive is it to Scheduled Castes and Scheduled Tribes?." Education Exclusion and Economic Growth Working paper series, vol. 1, no. 4, 2011.

Handbook on Social Welfare Statistics, Ministry of Social Justice and Empowerment, 2018. 
Human Development Report 2005, Government of Kerala, 2006.

Nath, Baiju K., and Anila. Developmental Programmes and Training Institution (CREST) for Scheduled castes \& Scheduled Tribes in Kerala.

Nath, Baiju K., and M. Ragi. Ekalayya Model Residential School for Tribal Students in Wayanad.

Nath, Baiju K., and Ruvega P.K. Parakandathil. Scheduled castes and Scheduled Tribes in India and their Higher Education.

Report on Scheduled Caste Habitats and Families in Kerala, SC Department, Government of Kerala, 2013.

Residential Schooling Strategies: Impact on Girls Education and Empowerment, Centre for Budget and Policy Studies, 2015.

Rupla Naik, B., et al. "Socio-Economic Empowerment of Tribes through Education: A Micro Level Study in Andhra Pradesh." Shanlax International Journal of Arts, Science and Humanities, vol. 6, no. 2, 2018, pp. 45-50.

Saravanakumar, S., and M. Palanisamy. "Status of Primary Education of Scheduled Caste Children." International Journal of Research in Humanities and Social Sciences, vol. 1, no. 8,2013 , pp. 54-61.
Satyasavitri, V.B., and P.M. Honakeri. "Impact of Ashram Schools Issues and Challenges of Tribal Education in India." International Journal of Scientific and Research Publications, vol. 8, no. 2, 2018, pp. 475-478. Scheduled Caste Development Department Kerala, https://scdd.kerala.gov.in

Sedwal, Mona, and Sangeeta Kamat. Education and Social Equity with a Special Focus on Scheduled Castes and Scheduled Tribes in Elementary Education, Research Monograph No.19, 2008.

Singh, Darshan. "Development of Scheduled Castes in India - A Review." Journal of Rural Development, vol. 28, 2009, pp. 529-542.

Suresha, R., and B. Mylarappa. "Socio-Economic Status of Rural Scheduled Caste Female Students in Higher Education." Indian Journal of Education and Information Management, vol. 1, no. 8, 2012, pp. 361-367.

Thangamani. "Education for Tribal Children: An Engine for Human Development." Shanlax International Journal of Education, vol. 3, no. 2, 2015, pp. 60-68.

www.censusindia.gov.in

https://kerala.gov.in

https://www.census2011.co.in/scheduled-castes.php

\section{Author Details}

Dr. P.M. Rejimon, Associate Professor, Post Graduate \& Research, Department of Economics, Mar Dionysius College, Pazhanji, Thrissur, Kerala, India, EmailID: pmrejimon@gmail.com

R. Smitha, Assistant Professor, Post Graduate \& Research, Department of Economics, Government College Thrissur, Kerala, India 